\title{
EXTERNAL FINANCE IN TRANSITION ECONOMIES: CGE MODELS APPLIED TO POLAND AND HUNGARY
}

\author{
S. I. COHEN \\ (Received: 14 September 2000; revision received: 13 November 2000, \\ accepted: 21 November 2000)
}

\begin{abstract}
The transition economies of Eastern Europe and the former Soviet Union have implemented at the eve of the transition public measures to promote economic growth and income protection. The success of the policies is very much dependent on the availability of external finance.

By calibrating for a country like Poland CGE models for 1987 and 1990 and simulating such measures it is possible to explore likely changes over these years and the effects of these measures on the sectoral and total levels of production, prices, as well as factor remuneration and use. The analysis is complemented with applications for Hungary in 1988 and 1990. The results show commonalties but also differences between the two countries in their dependence on foreign financial resources necessary for the transition.
\end{abstract}

Keywords: CGE models, transition, financial transfers

JEL classification index: $\mathrm{O} 2, \mathrm{P} 2, \mathrm{P} 5, \mathrm{H} 5$

\section{INTRODUCTION}

Systematic and reliable studies of actual processes of economic transition in relation to public policy face many difficulties. Transition from a centrally planned to a market oriented economy is characterised by a large number of mutual and conflicting policy measures, very often containing overlapping revisions induced by international and national political pressures, changes in ministers, correction of mistakes, and alike. Furthermore, there is the large array of interactions between economic agents which is barely understood and which has significant and unknown effects on expectations.

There are various courageous attempts to simulate public policy effects in particular transition economies. Most closely related to our paper are Commander

Correspondence: Erasmus University Rotterdam, Faculty of Economics, Post Box 1738, 3000 DR Rotterdam, The Netherlands. E-mail: cohen@few.eur.nl 
and Coricelli (1992), Kracun (1991), and Xu (1993), who try to predict the shortrun response of movements in prices, production, foreign trade and employment levels to public policy measures and to simulated external shocks. These attempts at prediction are faced with testing difficulties in situations of hectic price changes and unstable relations, which preclude the possibility of a reliable aggregation of data and empirical modelling during transition. It is not surprising, therefore, there are momentarily no agreed upon operational frameworks which are able to appraise policy measures against each other in transitional economies, or are able to monitor the actual results of any choice made.

In such circumstances, gaining insight in transition mechanisms and their bearing on public policy effects can only be obtained in pieces and with the use of highly simplified models of reality which focus only on a few crucial premises, one at a time. In this paper we make two types of premises which we use to develop an analytical framework worthful of producing some fruitful insights.

First, we take as a premise that the economy in transition will, after some time, finally function along the mechanisms of a Computable General Equilibrium (CGE), and that in the meantime it is approaching such a model. Discussion on the proper framework for the study of the transformation phenomena of planned economies to market economies is very controversial and unsettled. One simplification which is least ambitious, but nevertheless helpful in reflecting on performance aspects of the transformation process, is a comparative static analysis using a computable general equilibrium model, which is set in conformity with a baseline social accounting matrix (SAM). The SAM can be seen as a baseline measurement of the general equilibrium interactions in the economy for a particular year, and as such it forms a baseline for the calibration of CGE models.

As is well known the SAM displays the transactions of the economy with regard to receipts and expenditures of production activities, factors and institutions (whether households, firms, government or rest of the world) in a matrix form. Because of its algebraic properties the SAM can be viewed as a model of the economy. It can be broken down in an endogenous and an exogenous part, the latter can be recalculated as a matrix of proportional coefficients in terms of column totals, which can then be inverted to give multipliers which show the impacts of changes in the exogenous part on sectoral output, household incomes etc. The impact multipliers in a fixed price SAM model assume relative prices unchanged so that all impacts go into quantity changes. As such a SAM model can be seen to represent a truly centrally planned economy in which prices are fixed by the state and quantities carry the burden of the adjustment.

On the other hand, a free market economy is commonly modelled as a computable general equilibrium model. As is well known, the rules of the game in a CGE 
model are different from those in a fixed price SAM model. In the CGE model producers maximise their profits and consumers maximise their utility in markets in which the demand for and supply of products and factors are cleared at flexible equilibrium prices.

The SAM fixed price model and the CGE can be seen as the opposite poles between the central planning model and free market model. In another paper, we review applicability of both models to the modelling of economies in transition from a pure Centrally Planned Economy (CPE) to a pure Free Market Economy (FME), cf. Cohen et al. (1996).

It is a helpful simplification to assume that the transition economy moves from a CPE to a FME over a number of years. As the representation of the transition economy as a CGE model is more valid at later years than earlier years of the transition it is minimally required to model the performance of the economy at two consecutive periods so as to make possible a comparative static analysis. Accordingly, we shall proceed in this paper with calibrating, for a specific country, CGE models at two different periods in the transition.

Second, take as a premise, that how important the monetary side of the economy can be in the short run, it is as legitimate to gain insight by focussing on the real side of the economy in the long run. Leaving out the monetary side and the short-run aside requires working with real-side model without leakages to the money-side.

To analyse the influence of real market mechanisms on transitional policies in this perspective requires neutralising inflationary processes from the domestic economy. If transitional policies would include, for instance, a government expenditure on specific sectors or income transfers to specific groups, then the financing of these measures should not force the government to increase its budget debt, overextend money supply and set free inflationary pressures which would jeopardise the transitional process. Nor would a reshuffling of budget items be helpful in a situation of fixed resources. As it happens, the bilateral and multilateral financial institutions are aware of the impossibility of securing macro-economic stabilisation and price liberalisation in a transitional context without a substantial influx of external finance. The assumption which we shall make that policy measures pertaining to government expenditure are externally financed will not only circumscribe the model mechanisms to our desired focus but is also consistent with the actual form in which these policies are shaped.

The paper is organised as follows. Section 2 gives the model specification. Section 3 discusses results of two policy simulations for Poland, which is done under two model calibrations: for 1987 and 1990. Section 4 analyses corresponding results for Hungary. Section 5 ends with concluding remarks. 


\section{MODEL SPECIFICATIONS}

The SAMs constructed for Poland and Hungary relate to the years 1987 or 1988 and to 1990, just at the start of the transitional recession and somewhat half-way of the transitional recovery. The benchmark SAMs for these years are adapted versions of the SAMs compiled and published in Cohen (1993).

The CGE model applied in this paper portrays an idealised free market economy, which corresponds otherwise with the same distinctions of the constructed SAMs for Poland and Hungary.

The production activities belong to five sectors, namely agriculture, light industry, heavy industry, construction and services, this next to corresponding commodities linked to these sectors. The production activities are run by firms which produce and use factors of production such as labour and capital to the point of maximising profits subject to technological production constraints, taking all prices as given. There are households who are suppliers of labour and capital and demanders for commodities. They maximise utility subject to their budget constraint, again taking all prices as given. There is a social security agency, which is a passive body that accumulates and transfers funds. There is a government, which levies taxes and premiums and redistributes income over households. The government is also a demander and supplier of commodities. Finally there is the rest of the world which is engaged in trade and financial transfers with the domestic economy and which operates via foreign exchange rate.

All markets distinguished in the model, viz. the five goods markets, the two factor markets and the market for foreign exchange, are fully competitive. Demand and supply are equalised at all markets by instantaneous adjustment of all prices.

The equilibrium described by the model is of a static nature without intertemporal effects. In principle, the equilibrium solutions can be altered by the government through changes in its expenditure allocations and tax rates. However, we shall focus here on stimulus in expenditure allocations, which are assumed to be externally financed. As stated before, a typical feature of transition is that the expansive government policy regarding expenditure need to be externally financed if the transition should have any chance of success at all. Internal financing will create inflationary pressures, which will jeopardise macro-economic stability and liberalisation policies. This is also fully recognised by international donor and lending agencies, and they are committed to external financing during the transition.

The CGE model we use in this paper will apply the following notational conventions. Real variables are represented by lower case characters. All price variables are represented by a capital $P$ and a subscript identifying the corresponding 
real variables. Nominal variables are represented by capitals. Greek characters stand for parameters and coefficients. Activities are indicated by the subscripts $i$ and $j$, commodity categories by $k$. Households (and firms), social security, government, rest of the world are indicated by $h, s, g$ and $f$, respectively. Dollar signs refer to variables expressed in foreign currency. Exogenous variables are denoted by overbars. The two policy measures which will be simulated are: an externally financed expenditure allocation to a specific sector, denoted by $E F E_{\mathrm{i}}$; and an externally financed expenditure transfer to a specific household group, usually the poorest group, denoted by $\overline{E F E}_{h}$.

The complete model is specified as follows. Real output is determined from a two-level production structure. At the lowest level, sectoral real value-added ${ }_{i}$ is derived by a Cobb-Douglas function from labour $l_{i}$ and capital $k_{i}$, so smooth substitution possibilities exist at this level. The sectoral amount of capital is assumed to be fixed in the short run

$$
{ }_{i} \quad-{ }_{i 0} \quad l_{i}{ }^{i} \quad \bar{k}_{i}^{l}{ }^{i} .
$$

At the highest level real value-added is combined in fixed proportions with domestic and imported intermediate inputs to arrive at real output

$$
x_{i} \frac{i}{1 \quad j \quad j i \quad i} .
$$

The next equation gives the sector balances stating that nominal output by sector $X_{i}$ is equal to the sum of intermediate deliveries priced at the sector output prices $P_{x i}$, domestic consumption $C_{i}$, domestic investment $I_{i}$, and government expenditure whose volume is fixed at $C_{i g}$ and priced at $P_{x i}$. When we simulate an exogenously and externally financed government allocation to sector $i$, then the additional term $E F E_{i}$ becomes applicable

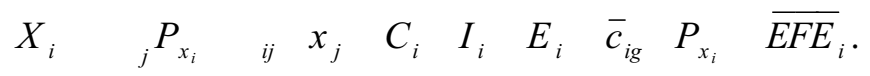

By definition the price of the output $P_{x i}$ is the nominal output divided by the real output

$$
X_{i} \quad P_{x_{j}} x_{i}
$$

Value-added prices $P_{i}$ can be derived by deducting indirect tax rates ${ }_{i}$ and unit costs of intermediate inputs from output prices. Imported intermediate goods are valued at exogenously fixed foreign prices $\bar{P}_{m_{i}}^{\$}$, which are transformed into domestic currency by multiplying with the exchange rate $R$ 


$$
P_{i} \quad\left(1 \quad{ }_{i}\right) P_{x_{i}} \quad j_{j i} \quad P_{x_{j}} \quad{ }_{i} \quad R \quad \bar{P}_{m_{i}}^{\$} .
$$

Each sector is assumed to consist of many similar firms, which all maximise profits in perfectly competitive product and labour markets. The latter implies that wage and prices are given for the individual firm and this allows us to treat each sector as one large price-taking firm. Following first order conditions for profit maximisation firms will hire labour $l_{i}$ until the wage rate $P_{l}$ equals the value of its marginal product

$$
\begin{array}{lllll}
P_{l} & l_{i} \quad{ }_{i} & P_{i} & x_{i}
\end{array}
$$

The remuneration of capital is the residual nominal value-added after labour is paid its share. Because the volume of capital is fixed, remuneration rates $P_{k_{i}}$ have to adjust to be equal to the value of marginal product of capital. Consequently, remuneration rates of capital may differ among sectors

$$
\left.\begin{array}{llll}
P_{k_{i}} & \bar{k}_{i} & (1 & i
\end{array}\right) P_{i} x_{i} .
$$

Total demand for labour is equal to the exogenous supply. The wage rate is solved from this equilibrium equation

$$
{ }_{i} l_{i} \quad \bar{l} .
$$

Primary income of institutions $Y^{p}$ consists of factor remuneration, which are distributed in fixed proportions. Primary income of government comprises also indirect taxes

$$
\begin{aligned}
& Y_{h}^{p} \quad{ }_{h} \quad P_{l} \quad \bar{l} \quad h_{i} \quad P_{k_{i}} \bar{k}_{i} \\
& \begin{array}{llllllll}
Y_{s}^{p} \quad{ }_{s} & P_{l} & \bar{l} & & & P_{i} & P_{k_{i}} & \bar{k}_{i}
\end{array} \\
& \begin{array}{lllllllllllll}
Y_{g}^{p} & { }_{g} & P_{l} & \bar{l} & g & { }_{i} P_{k_{i}} & \bar{k}_{i} & { }_{i} & { }_{i} & P_{x_{i}} & x_{i} .
\end{array}
\end{aligned}
$$

Households and firms pay (direct) tax to the government. Direct tax is levied over taxable income $Y^{t}$. Taxable income comprises primary income and income transfers received from government, social security and from abroad. Income transfers paid by government and social security are exogenous in real terms. Nominal transfers are pegged to the consumer price index CPI to maintain purchasing power of households at the benchmark level. The consumer price index is chosen as numeraire of the model and is fixed exogenously. Transfers from abroad are fixed in foreign currency and are transformed to domestic currency by 
multiplication with the exchange rate $R$. Transfers to firms are zero in the SAM, so for firms taxable income is implicitly equal to primary income

$$
\begin{array}{llllll}
Y_{h}^{t} & Y_{h}^{p} & \bar{o}_{h g} & \overline{C P I} & \bar{o}_{h f} & R .
\end{array}
$$

Disposable income of households and firms $Y$ is defined as taxable income minus direct taxes and social security contributions paid. Both social security contributions and direct taxes are fixed proportions ( ${ }_{s h}$ and ${ }_{g h}$ respectively) of taxable income. When we simulate an exogenously and externally financed government transfer to a specific household group, say the poorest, then the additional term $\overline{E F E}_{h}$ becomes applicable

$$
Y_{h}^{d} \quad(1 \quad s h \quad g h) Y_{h}^{t} \quad \overline{E F E}_{h} .
$$

Most outlays by social security are fixed in real terms. Nominal transfers paid to domestic and foreign households are pegged to the consumer price index, as the objective of the government is to maintain purchasing power of transfer payments. Because savings of social security $S_{s}$ are a provision for future fluctuations in the number of transfers, they are pegged to the consumer price index also. Incomings are primary income and social security contributions paid by households. The budget is balanced by adjusting the net transfers paid to the government $O_{g s}$

$$
\begin{array}{lllllllllllll}
Y_{s}^{p} & \quad{ }_{h} & s h & Y_{h}^{t} & \bar{s}_{s} & \overline{C P I} & { }_{h} \bar{o}_{h s} & \overline{C P I} & \bar{o}_{f s} & \overline{C P I} & O_{g s} .
\end{array}
$$

The government budget deficit, in the situation without a simulated change in government expenditure, $D_{g o}$, is defined as incomings minus expenditures. Incomings are primary income and direct taxes paid by households and firms. Government expenditures are fixed in real terms. In addition to spending on consumption and investment, of which the volume $c_{i g}$ is fixed exogenously, government spends also on transfers

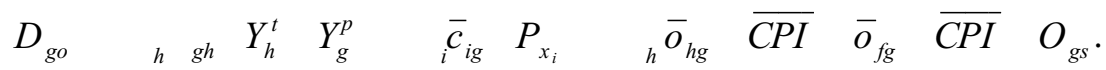

When an exogenously and externally financed expenditure expansion is simulated, say $\overline{E F E}_{i}$ or $\overline{E F E}$, another government budget as a result of the simulation is obtained, denoted by $D_{g n}$. This is defined below

$$
D_{g n} \quad D_{g o} \quad \overline{E F E}_{i} \quad \overline{E F E}_{h} .
$$

Consumption expenditure of households is distinguished by commodity categories $W_{k h}$. For simplicity it is assumed that consumption behaviour is determined 
by Cobb-Douglas utility functions, which generates the following constant budget shares consumption demand function

$$
\bar{W}_{k h} \quad{ }_{k h} Y_{h}^{d} .
$$

Commodities $k$ are composed of domestic goods distinguished by sector of origin $i$, and imported goods denoted by $f$. The volume shares of the two types in the composite are respectively fixed, ${ }_{i k}$ and $f k$. Thus, no substitution is possible between domestic and imported goods. Domestic goods consumption by sector, $C_{i}$, can be derived as follows

$$
Q_{i} \quad P_{x_{i}} \quad k_{k i k} \quad{ }_{h} \frac{W_{k h}}{P_{w_{k}}} .
$$

Consumption expenditure composed of imported goods $M_{k}$ is as follows

$$
M_{k} \quad \bar{P}_{m_{k}}^{\$} \quad R \quad{ }_{f k} \quad{ }_{h}^{h} \frac{W_{k h}}{P_{w_{k}}} .
$$

The price index of commodities $P_{w k}$ is a weighted average of all component prices. The weights are the respective shares of the components in the composite

$$
\begin{array}{lllll}
P_{w_{k}} \quad{ }_{j k} & \bar{P}_{m_{w}}^{\$} & R \quad{ }_{i} i k & P_{x_{i}} .
\end{array}
$$

The closure of the model is neoclassical, which implies that domestic investment expenditure $Z$ is determined by the sum of domestic and foreign savings. Total domestic savings are the sum of savings by government, social security and households and firms, the latter is defined as disposable income minus consumption expenditure. Net foreign savings consist of exogenous flow $F^{\$}$, which is fixed in foreign currency, and an endogenous flow which is equal to the government budget deficit, as it is assumed that the government finances its total budget deficit by foreign borrowing. As the endogenous part of foreign savings cancels out against net government savings both are excluded from the following equation

$$
\begin{array}{lllllllll}
Z & \bar{F}^{\$} & R & \bar{s}_{s} & \overline{C P I} & { }_{h} Y_{h}^{d} & { }_{h} & { }_{k} W_{k h} .
\end{array}
$$

It is assumed that there exists only one type of investment good, which is a composite of a domestic component of capital goods, again distinguished by sector of origin, and an imported component of capital goods. The volume shares of the delivering sectors in the composite ${ }_{i}$ are fixed. Nominal investment expenditure by sector of origin $I_{i}$, as far as the domestic component is concerned, is specified below 


$$
I_{i} \quad P_{x_{i}} \quad i \frac{Z}{P_{Z}} \text {. }
$$

The price index of the composite investment good $P_{Z}$ is a weighted average of domestic output prices $P_{x_{i}}$ and the price index of a composite of imported investment goods $P_{z}$. The weights are the respective shares of the components in the composite

$$
P_{Z} \quad f^{\prime} \quad \bar{P}_{m_{Z}}^{\$} R \quad i_{i} i P_{x_{i}} .
$$

Domestic products are assumed to compete on the world market with goods produced abroad, which differ by country of origin. This product heterogeneity implies that the world market demand for domestic products depends partly on domestic prices. Then, the value of exports $E_{i}$ can be expressed as follows:

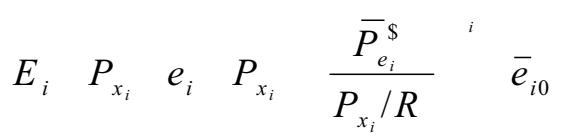

where $e_{i}$ is the volume of exports, $P_{e_{i}}^{\$}$ is the weighted average of the fixed prices of competitors on the world market and ${ }_{i}$ is the world market demand elasticity for domestic products of sector $i . \bar{e}_{i 0}$ is a constant term reflecting total world market demand for output of sector $i$ and the domestic market share if $P_{x_{i}} / R$ is equal to $P_{e_{i}}$. If it is assumed that the export demand elasticity is equal to one, we get:

$$
E_{i} \quad \bar{P}_{e_{i}}^{\$} \quad R \quad \bar{e}_{i 0} .
$$

The balance of payments equation gives on the left-hand side the capital account balance. On the capital account a distinction is made between the inflow of foreign capital needed to finance the government budget deficit $D^{g w}$ and other capital flows $F^{\$}$, which are fixed in foreign currency. The right-hand side gives the current account balance, which consists of imports of investment goods, intermediate goods and consumption goods, exports and net income transfers to abroad

$$
\begin{array}{ccccccccccc}
\bar{F}^{\$} & R & D_{g n} & \bar{P}_{m_{Z}}^{\$} & R & f & \frac{Z}{P_{z}} & { }_{i} \bar{P}_{m_{i}} & R & { }_{i} & x_{i} \\
& { }_{k} M_{k} & { }_{i} E_{i} & \left(\bar{o}_{f g}\right. & \left.\bar{o}_{f s}\right) & \overline{C P I} & { }_{h} \bar{o}_{h f} & R .
\end{array}
$$

Finally, the consumer price index is taken as numeraire of the model. The weights are the proportions of the respective products in aggregate household expenditure. This specification implies that changes in household income can be interpreted as changes in real household income 


$$
\overline{C P I} \quad{ }_{k} \quad{ }_{k} P_{w_{k}} .
$$

As stated before this CGE model is calibrated using the SAM as the baseline. Externally financed policy simulations are then carried out as reported below.

\section{RESULTS OF INTERNALLY FINANCED PUBLIC MEASURES IN POLAND}

As was stated before, to demonstrate the different consequences of government policy under transitional conditions two measures are simulated. The first is aimed at enhancing the production of services, which is well known to have been especially neglected under centrally planned regimes. The second is aimed at changing the income distribution in favour of the poorest households, which are specially disadvantaged during the transition. In the first, simulation I, government demand for services is increased by $1 \%$ of total government expenditure. The relevant variable here is $\overline{E F E}_{i}$, where $i$ refers to the services sector. The measure can be interpreted as been taken to reduce the bias against the underdeveloped service sector inherited from the old planning system. In the second, simulation II, the same amount is transferred as welfare payments to the lowest decile household group, which can be interpreted as a measure to reduce the adverse effects of transition for the poorest households. The relevant variable here is $\overline{E F E}_{h}$, where $h$ refers to the poorest decile. In both cases it is assumed that the stimulus will be fully or partially financed by external resources so as to guarantee that the budget deficit is not raised, and that the government is not pushed into inflationary actions.

The exogenous impulse of $1 \%$ of total government expenditure was equal to 31,197 bill. $\mathrm{zl}$ for 1987 and 1,144 th. bill. $\mathrm{zl}$ for 1990. These figures are close to each other when considered as relative magnitudes. They form respectively $0.18 \%$ and $0.19 \%$ of the GDP in the two years. The results of the simulations are presented in Tables 1, 2, 3 and 4. These results will be discussed for each of simulations I and II. The results for a specific variable is presented as a percentage deviation from the value of the variable in the baseline SAM, which is the equilibrium situation preceding the simulated government action.

Simulation I. Comparing the CGE calibration for 1987 and 1990 it is noted that the additional government demand for services leads to an increase in the nominal output of services (of $1.57 \%$ in 1987 and equally $1.57 \%$ in 1990). Since total factor supplies are given, part of the increase in demand disappears into a rise in the price index of services $(0.84 \%$ in 1987 and $0.92 \%$ in 1990), so that the real increase in output of services is smaller: $0.72 \%$ in 1987 and $0.65 \%$ in 1990 . In general, as factor supplies are given, the rise in output of services can now be realised 
only through reallocation of factor supplies from other activities; this is restricted to the reallocation of labour, since capital is immobile. So, if services are enhanced some sectors are bound to shrink. The construction sector is enhanced, heavy industry is adversely affected, while agriculture and light industry are not much affected.

The construction sector is enhanced from the expansion of services through various mechanisms. Real production of construction has increased by $0.57 \%$ in 1987 (and by $0.43 \%$ in 1990). This is partly caused by substantial forward linkages of services to construction and partly by the boost in investment expenditure that amounts to $0.96 \%$ in 1987 (0.76\% in 1990).

It is heavy industry, which is to a large extent reliant on exports, that suffers most from the stimulus. Real output decreases by $-0.63 \%$ in $1987(-0.49 \%$ in 1990). The mechanism goes along the following lines. The government budget deficit rises through the increase in spending. It is assumed that the creditworthiness of the transitional policies of the government and the international support of this transition are sufficient to enable the government to finance the deficit by foreign grants or borrowing. This leads to an increase in the supply of foreign currency, inducing an appreciation of the zloty: the exchange rate has to decrease by $-4.13 \%$ in $1987(-2.69 \%$ in 1990$)$ to restore equilibrium on the balance of payments. The appreciation deteriorates the competitive position of Polish exporters and exports will decrease. So, exports - especially of heavy industry - carry the burden of the macro-economic adjustment and have to give in to make the expansion of government expenditure possible.

Finally, there is an increase in the production level of agriculture and a decrease in light industry, but these are less pronounced. Both sectors have a more diversified demand structure and are less vulnerable to changes in the pattern of final demand.

An important additional effect of the appreciation of the zloty is a strong improvement in the terms of trade, which is manifested by high value-added prices. This leads to a considerable increase in the total value-added, or GDP, namely by $0.87 \%$ in 1987 and $0.57 \%$ in 1990 . This positive development occurs in spite of fixed resources and is due to the stimulus of external finance.

The labour share of the value-added increases, the share of capital decreases, which is an indication of a shift in factor use towards more labour intensive activities.

The rise in factor payments results in an increase in household income, averaging $0.72 \%$ for 1987 (0.47\% in 1990), but this rise in household income is smaller than the rise in factor payment, because part of household income stems from fixed income transfers. The distribution of income on the deciles shows for 1986 the poorest deciles to gain smaller increases in income as compared to the richer 
Table 1

Poland: Results of the simulations for 1987 expressed as percentage deviations from SAM values

\begin{tabular}{|c|c|c|}
\hline \multirow{2}{*}{ Accounts } & \multicolumn{2}{|c|}{ CGE Model } \\
\hline & Simulation I & Simulation II \\
\hline \multicolumn{3}{|l|}{ Receipts of activities } \\
\hline Agriculture & 0.22 & 0.34 \\
\hline Light industry & -0.23 & 0.01 \\
\hline Heavy industry & -0.95 & -0.69 \\
\hline Construction & 1.31 & 1.04 \\
\hline Services & 1.57 & 0.80 \\
\hline Average & 0.32 & 0.30 \\
\hline \multicolumn{3}{|l|}{ Receipts of factors } \\
\hline Labour & 0.91 & 0.69 \\
\hline Capital & 0.82 & 0.64 \\
\hline Average & 0.87 & 0.66 \\
\hline \multicolumn{3}{|l|}{ Receipts of institutions } \\
\hline 1st decile household & 0.66 & 9.07 \\
\hline 2nd decile household & 0.67 & 0.51 \\
\hline 3rd decile household & 0.66 & 0.50 \\
\hline 4th decile household & 0.66 & 0.50 \\
\hline 5th decile household & 0.67 & 0.50 \\
\hline 6th decile household & 0.70 & 0.53 \\
\hline 7th decile household & 0.70 & 0.53 \\
\hline 8th decile household & 0.73 & 0.55 \\
\hline 9th decile household & 0.76 & 0.58 \\
\hline 10th decile household & 0.78 & 0.59 \\
\hline Average & 0.72 & 0.87 \\
\hline Firms & 0.79 & 0.61 \\
\hline Capital & 0.98 & 0.78 \\
\hline \multicolumn{3}{|l|}{ Macro-indicators } \\
\hline GDP & 0.87 & 0.66 \\
\hline Investment & 0.96 & 0.78 \\
\hline Domestic savings & 0.59 & 0.43 \\
\hline Private consumption & 0.72 & 0.87 \\
\hline Imports & -4.06 & -3.10 \\
\hline
\end{tabular}

Table 2

Poland: Results of the simulations for 1987 (price and quantity variables in percentage deviations from SAM values)

\begin{tabular}{|c|c|c|c|c|c|c|c|c|}
\hline \multirow[b]{2}{*}{ Activities } & \multicolumn{4}{|c|}{ Simulation I } & \multicolumn{4}{|c|}{ Simulation II } \\
\hline & $\begin{array}{c}\text { nominal } \\
\text { output }\end{array}$ & $\begin{array}{c}\text { real } \\
\text { output }\end{array}$ & $\begin{array}{l}\text { output } \\
\text { prices }\end{array}$ & $\begin{array}{c}\text { VA } \\
\text { prices }\end{array}$ & $\begin{array}{c}\text { nominal } \\
\text { output }\end{array}$ & $\begin{array}{c}\text { real } \\
\text { output }\end{array}$ & $\begin{array}{l}\text { output } \\
\text { prices }\end{array}$ & $\begin{array}{c}\text { VA } \\
\text { prices }\end{array}$ \\
\hline Agriculture & 0.21 & -0.21 & 0.42 & 0.81 & 0.34 & -0.02 & 0.36 & 0.67 \\
\hline Light industry & -0.23 & -0.18 & -0.05 & 0.71 & 0.01 & -0.01 & 0.02 & 0.68 \\
\hline Heavy industry & -0.95 & -0.63 & -0.32 & 0.09 & -0.69 & -0.46 & -0.23 & 0.09 \\
\hline Construction & 1.31 & 0.57 & 0.74 & 1.71 & 1.04 & 0.46 & 0.58 & 1.33 \\
\hline Services & 1.56 & 0.72 & 0.84 & 1.53 & 0.80 & 0.30 & 0.50 & 0.94 \\
\hline
\end{tabular}

Acta Oeconomica $51(2000 / 2001)$ 
Table 3

Poland: Results of the simulations for 1990 expressed as percentage deviations from SAM values

\begin{tabular}{|c|c|c|}
\hline \multirow{2}{*}{ Accounts } & \multicolumn{2}{|c|}{ CGE Model } \\
\hline & Simulation I & Simulation II \\
\hline \multicolumn{3}{|l|}{ Receipts of activities } \\
\hline Agriculture & -0.18 & 0.08 \\
\hline Light industry & -0.31 & 0.00 \\
\hline Heavy industry & -0.86 & -0.57 \\
\hline Construction & 0.94 & 0.78 \\
\hline Services & 1.57 & 0.79 \\
\hline Average & 0.38 & 0.21 \\
\hline \multicolumn{3}{|l|}{ Receipts of factors } \\
\hline Labour & 0.65 & 0.46 \\
\hline Capital & 0.52 & 0.39 \\
\hline Average & 0.57 & 0.42 \\
\hline \multicolumn{3}{|l|}{ Receipts of institutions } \\
\hline 1st decile household & 0.09 & 5.47 \\
\hline 2nd decile household & 0.26 & 0.18 \\
\hline 3rd decile household & 0.37 & 0.26 \\
\hline 4th decile household & 0.41 & 0.29 \\
\hline 5th decile household & 0.47 & 0.33 \\
\hline 6th decile household & 0.48 & 0.34 \\
\hline 7th decile household & 0.53 & 0.38 \\
\hline 8th decile household & 0.55 & 0.39 \\
\hline 9th decile household & 0.57 & 0.41 \\
\hline 10th decile household & 0.57 & 0.41 \\
\hline Average & 0.47 & 0.67 \\
\hline Firms & 0.52 & 0.39 \\
\hline Capital & 0.76 & 0.59 \\
\hline \multicolumn{3}{|l|}{ Macro-indicators } \\
\hline GDP & 0.57 & 0.42 \\
\hline Investments & 0.76 & 0.59 \\
\hline Domestic savings & 0.04 & 0.00 \\
\hline Private consumption & 0.46 & 0.73 \\
\hline Imports & -2.54 & -1.77 \\
\hline
\end{tabular}

Table 4

Poland: Results of the simulations for 1990 (price and quantity variables in percentage deviations from SAM values)

\begin{tabular}{|c|c|c|c|c|c|c|c|c|}
\hline \multirow[b]{2}{*}{ Activities } & \multicolumn{4}{|c|}{ Simulation I } & \multicolumn{4}{|c|}{ Simulation II } \\
\hline & $\begin{array}{c}\text { nominal } \\
\text { output }\end{array}$ & $\begin{array}{c}\text { real } \\
\text { output }\end{array}$ & $\begin{array}{l}\text { output } \\
\text { prices }\end{array}$ & $\begin{array}{l}\mathrm{VA} \\
\text { prices }\end{array}$ & $\begin{array}{c}\text { nominal } \\
\text { output }\end{array}$ & $\begin{array}{c}\text { real } \\
\text { output }\end{array}$ & $\begin{array}{l}\text { output } \\
\text { prices }\end{array}$ & $\begin{array}{c}\mathrm{VA} \\
\text { prices }\end{array}$ \\
\hline Agriculture & -0.19 & -0.36 & 0.17 & 0.48 & 0.07 & -0.10 & 0.17 & 0.41 \\
\hline Light industry & -0.15 & -0.23 & 0.08 & 0.30 & 0.00 & -0.04 & 0.04 & 0.30 \\
\hline Heavy industry & -0.86 & -0.49 & -0.37 & -0.24 & -0.57 & -0.33 & -0.24 & -0.24 \\
\hline Construction & 0.93 & 0.43 & 0.50 & 1.50 & 0.78 & 0.36 & 0.42 & 1.17 \\
\hline Services & 1.57 & 0.65 & 0.92 & 1.39 & 0.79 & 0.28 & 0.51 & 0.78 \\
\hline
\end{tabular}


deciles, which gain relatively more. These tendencies are accelerated for 1990 and reflect a regressive bias during transition. The SAM baselines for Poland indicate that the share of income earnings in the income of the poorest households, have significantly fallen down in three years time. The foremost source of income for these groups has taken the form of transfers.

Private consumption increases through the rise in household income by $0.72 \%$ in 1987 (0.46\% in 1990). Higher household and firm incomes result in higher tax receipts by the government. This mitigates the initial increase in the budget deficit, so that in the end the increase in private and foreign savings dominates the decrease in government savings. The neoclassical closure of the model implies that investment will rise at a rate equal to the increase in total savings: $0.96 \%$ in 1987 and $0.76 \%$ in 1990 .

Simulation II. In the CGE model, additional government transfers to the lowest decile household group results in significant increases in incomes of those households (by $9.05 \%$ in 1987 and 5.47\% in 1990), other household groups improve their income too but only marginally.

Total consumption expenditure increases by approximately the same rate as the average of household incomes but its pattern changes towards a larger share of foodstuffs and other necessities. Consumption demand has increased more than in the previous simulation, which follows from the fact that in the current simulation household incomes are affected directly by the government impulse, while in the previous simulation incomes were only indirectly influenced.

As for the sectoral effects, the large increase in consumption, and the consumption of foodstuffs in particular, has a favourable effect on the production of agriculture and light industry. However, this impact is not enough to offset the decrease in these activities' export earnings so that real production in agriculture and light industry decreases by $0.02 \%$ and $-0.01 \%$ respectively in $1987(-0.10 \%$ and $-0.04 \%$ in 1990 , respectively). Services expand by $0.30 \%$ in $1987(0.28 \%$ in 1990), mainly through trade, which increases with consumption and investment. The increase in investment also causes a sharp rise in the production level of construction: $0.46 \%$ in 1987 and $0.36 \%$ in 1990 . Heavy industry undergoes the largest decline in production, resulting from its strong dependence on exports. In this, as in other simulations, exports have to give in to realise the increase in domestic demand.

When growth of all sectors is summed, the GDP is shown to increase by $0.6 \%$ on the 1987 baseline, and a smaller increase at $0.43 \%$ for the 1990 baseline.

Further discussions of results. Under the simulated model the price changes, more in particular a decrease in the exchange rate, are responsible for the increase in domestic income. Since total resources are fixed, price changes cannot generate a rise in income for all actors in the system, they can only redistribute income be- 
tween actors. In this model the rest of the world pays for the increase in domestic incomes, while the distributionary mechanisms in the transition economy determines who gets what. Of course, the favourable impact of the increase in foreign borrowing only holds if the external financing is in the form of grants. In the longer run debts have to be amortised and interest has to be paid if external financing is in the form of loans.

A comparison of results between 1987 and 1990 shows the positive impact on sectoral output and household income to become less pronounced as the transition proceeds. This holds for both simulations. This reduced positive impact is explained by the smaller change in the exchange rate in 1990. The lower exchange rate results from the increase in exports relative to imports between 1987 and 1990. Higher exports facilitate the adjustment to balance of payments equilibrium, because the adjustment takes place mainly through changes in exports, since imports are non-competitive and thus do not react directly to changes in the exchange rate.

So, in conclusion we can say that the level of exports relative to imports plays an important role in determining the effect a transition will have on household incomes. Apart from this, the effect does depend on the assumed substitution elasticities. For the current simulations, we have chosen for specifications that allowed all parameters to be calibrated by the SAM, which implicitly means that the substitution elasticity was zero for import demand and unity for export demand. For future simulations it will be useful to use substitution elasticities with greater empirical validity.

\section{COMPARATIVE RESULTS FOR HUNGARY}

The same CGE models were also calibrated on a similar classification of SAMs for Hungary for an early transition year and a later transition year, 1988 and 1990 respectively. Because the format of the Hungarian SAM deviates slightly from the format of the Polish SAM, some minor adjustments in the CGE model were necessary. ${ }^{1}$

1 The adjustments are the following:

(a) Capital income in Hungary is not distributed directly to the households as a total proportion of capital income, but flows to the firms and is distributed over the households as a fixed proportion of firm income.

(b) Government sector comprises also social security.

(c) Firms are allowed to buy consumption goods.

(d) Indirect taxes are levied not only on production but also on consumption and imported investment goods. 
The two experiments undertaken with the Polish model were repeated for Hungary. In the first simulation, simulation I, government demand for services was increased by $1 \%$ of total government expenditure, while in the second simulation, simulation II, the transfers to the poorest household group were increased by the same amount. Expressed as a percentage of the GDP the impulse was about the same in 1988 and 1990. The simulation results for 1988 are in Tables 5 and 6 and the results for 1990 are in Tables 7 and 8 .

Simulation I. In Hungary the macro adjustment to external shocks goes along the same lines as in Poland. The increase in government spending leads to a decline in the government budget surplus and results in a cutback of net debt amortisation by the government, which reduces the demand for foreign currency so that the forint appreciates. The decrease in the exchange rate amounts to $-2.29 \%$ in 1988 and to $-2.69 \%$ in 1990 . The resulting decrease in exports makes possible the expansion of government (in the services simulation) and private consumption (in the transfer simulation).

Contrary to the Polish situation there is no boost in investment expenditure in Hungary. The reason for this is the high exogenous inflow of foreign capital. The fall in the exchange rate reduces the domestic value of these foreign savings and this offsets the increase in domestic savings resulting from increased incomes. The outcome is a small decline in investment expenditure.

On the sectoral level the shift to more services has least affects on construction, because its strong linkages with investment have a stabilising effect on its output, while direct injections to services have also a favourable impact on forward deliveries. The latter effect is due to the high construction intensity of services. The output of construction declines in real terms by $-0.10 \%$ in 1988 and by $-0.01 \%$ in 1990. Agriculture and light industry undergo a considerable decline in real output: $-0.29 \%$ and $-0.32 \%$ respectively in $1988(-0.36 \%$ and $-0.44 \%$, respectively, in 1990); for light industry nominal output has decreased even more, because the output price has decreased also. Heavy industry suffers the most because of its strong dependence on declining exports, the decline in real output amounts to -0.78 in $1988(-0.83 \%$ in 1990$)$, which is a larger decline than in the Polish simulations. In contrast, the increase in the service sector $(1.02 \%$ in 1988 and $0.83 \%$ in 1990) is much larger than in the Polish simulations. The results indicate a larger dispersion of sectoral effects in Hungary than in Poland. When all increases in real output are multiplied by their respective VA prices the results for Hungary show the percentage change in the GDP to be $0.90 \%$ for 1988 and $0.87 \%$ for 1990 . These Hungarian figures are higher than the Polish ones.

The growth in labour income exceeds the growth in capital income by 0.16 percentage point in 1988 and 0.1 percentage point in 1990. This difference is caused 
by the decline of output of the capital-intensive industrial sectors. However, the shift from capital to more labour intensive sectors is much more pronounced in Poland.

Average household income increases by $0.73 \%$ in 1988 and by $0.67 \%$ in 1990 . The simulation shows that the resulting distribution of income becomes more unequal as compared to the 1988 baseline. The same pattern is obtained for 1990, and there is thus no increase in regressiveness between the two years. In contrast, it is recalled that the regressiveness increases in Poland during the transition process.

Simulation II. The additional transfer increases the income of the lowest decile by $13.47 \%$ in 1988 and $14.00 \%$ in 1990 . Other deciles increase their income only marginally by percentages which range between $0.34 \%$ and $0.52 \%$. When the distribution bias of the transfer is evaluated for the two countries it appears that the lowest income decile benefits relatively more in Hungary than in Poland.

On the sectoral level, output of agriculture is positively influenced by the increase in consumption and negatively by the fall in exports and the fall in output of light industry, to which it has strong forward linkages. Both effects outweigh each other and ultimately there is hardly any change in output. Heavy industry suffers the most, real output declines by $0.45 \%$, both in 1988 and 1990 . The decline is caused by the decrease in export earnings. In nominal terms the decline is reinforced by a fall in the output price. For the same reason real output of light industry falls slightly. The service sector benefits most from the increase in transfers to the poorest household; its real output rises by $0.35 \%$ in 1988 and by $0.26 \%$ in 1990. Services are strongly linked to consumption, while they are not affected by the constant or falling export demand. Constant government consumption of services in case of injections to the poorest households can be viewed as a stabilising factor in CGE models (since total output is fixed).

Though in the individual sectors labour and capital income change at the same rate due to the assumptions of the model, the expansion of the service sector, which has a small bias in favour of labour, combined with the worse performance of the capital-intensive industrial sectors has the effect that labour income grows slightly more than capital income. Average factor income or GDP grows by $0.57 \%$ in 1988 and $0.55 \%$ in 1990 . These two rates are close to each other. It is recalled that this simulation gave for Poland a larger range of GDP growth of $0.66 \%$ and $0.42 \%$, respectively. 
Table 5

Hungary: Results of the simulations for 1988

expressed as percentage deviations from SAM totals

\begin{tabular}{|c|c|c|}
\hline \multirow{2}{*}{ Accounts } & \multicolumn{2}{|c|}{ CGE Model } \\
\hline & Simulation I & Simulation II \\
\hline \multicolumn{3}{|l|}{ Receipts of activities } \\
\hline Agriculture & -0.03 & 0.20 \\
\hline Light industry & -0.54 & -0.10 \\
\hline Heavy industry & -1.02 & -0.58 \\
\hline Construction & 0.20 & 0.15 \\
\hline Services & 1.70 & 0.72 \\
\hline Average & 0.06 & 0.08 \\
\hline \multicolumn{3}{|l|}{ Receipts of factors } \\
\hline Labour & 0.95 & 0.59 \\
\hline Capital & 0.79 & 0.53 \\
\hline Average & 0.87 & 0.56 \\
\hline \multicolumn{3}{|l|}{ Receipts of institutions } \\
\hline 1st decile household & 0.55 & 13.47 \\
\hline 2nd decile household & 0.60 & 0.38 \\
\hline 3rd decile household & 0.64 & 0.40 \\
\hline 4th decile household & 0.66 & 0.41 \\
\hline 5th decile household & 0.68 & 0.43 \\
\hline 6th decile household & 0.70 & 0.44 \\
\hline 7th decile household & 0.73 & 0.46 \\
\hline 8th decile household & 0.76 & 0.48 \\
\hline 9th decile household & 0.78 & 0.49 \\
\hline 10th decile household & 0.83 & 0.52 \\
\hline Average & 0.73 & 1.05 \\
\hline Firms & 0.79 & 0.53 \\
\hline Capital & -0.32 & -0.12 \\
\hline \multicolumn{3}{|l|}{ Macro-indicators } \\
\hline GDP & 0.90 & 0.57 \\
\hline Investment & -0.32 & -0.12 \\
\hline Domestic savings & -0.35 & -0.35 \\
\hline Private consumption & 0.73 & 1.09 \\
\hline Imports & -2.44 & -1.38 \\
\hline
\end{tabular}

\section{Table 6}

Hungary: Results of the simulations for 1988 (price and quantity variables in percentage deviations from SAM values)

\begin{tabular}{|c|c|c|c|c|c|c|c|c|}
\hline \multirow[b]{2}{*}{ Activities } & \multicolumn{4}{|c|}{ Simulation I } & \multicolumn{4}{|c|}{ Simulation II } \\
\hline & $\begin{array}{c}\text { nominal } \\
\text { output }\end{array}$ & $\begin{array}{c}\text { real } \\
\text { output }\end{array}$ & $\begin{array}{l}\text { output } \\
\text { prices }\end{array}$ & $\begin{array}{c}\mathrm{VA} \\
\text { prices }\end{array}$ & $\begin{array}{c}\text { nominal } \\
\text { output }\end{array}$ & $\begin{array}{c}\text { real } \\
\text { output }\end{array}$ & $\begin{array}{l}\text { output } \\
\text { prices }\end{array}$ & $\begin{array}{c}\text { VA } \\
\text { prices }\end{array}$ \\
\hline Agriculture & -0.03 & -0.29 & 0.26 & 0.90 & 0.20 & 0.01 & 0.19 & 0.59 \\
\hline Light industry & -0.54 & -0.32 & -0.22 & 0.67 & -0.10 & -0.02 & -0.08 & 0.58 \\
\hline Heavy industry & -1.02 & -0.78 & -0.24 & 0.43 & -0.58 & -0.45 & -0.13 & 0.30 \\
\hline Construction & 0.20 & -0.10 & 0.30 & 0.92 & 0.16 & -0.04 & 0.20 & 0.58 \\
\hline Services & 1.70 & 1.02 & 0.68 & 1.40 & 0.71 & 0.35 & 0.36 & 0.75 \\
\hline
\end{tabular}

Acta Oeconomica 51 (2000/2001) 
Table 7

Hungary: Results of the simulations for 1990

expressed as percentage deviations from SAM totals

\begin{tabular}{|c|c|c|}
\hline \multirow{2}{*}{ Accounts } & \multicolumn{2}{|c|}{ CGE Model } \\
\hline & $\mathrm{S}$ & $\mathrm{H}$ \\
\hline \multicolumn{3}{|l|}{ Receipts of activities } \\
\hline Agriculture & -0.18 & 0.16 \\
\hline Light industry & -0.76 & -0.21 \\
\hline Heavy industry & -1.12 & -0.61 \\
\hline Construction & 0.27 & 0.24 \\
\hline Services & 1.49 & 0.62 \\
\hline Average & -0.06 & 0.04 \\
\hline \multicolumn{3}{|l|}{ Receipts of factors } \\
\hline Labour & 0.89 & 0.56 \\
\hline Capital & 0.79 & 0.52 \\
\hline Average & 0.84 & 0.54 \\
\hline \multicolumn{3}{|l|}{ Receipts of institutions } \\
\hline 1st decile household & 0.49 & 14.00 \\
\hline 2nd decile household & 0.54 & 0.34 \\
\hline 3rd decile household & 0.58 & 0.37 \\
\hline 4th decile household & 0.59 & 0.38 \\
\hline 5th decile household & 0.61 & 0.38 \\
\hline 6th decile household & 0.64 & 0.40 \\
\hline 7th decile household & 0.67 & 0.42 \\
\hline 8th decile household & 0.70 & 0.44 \\
\hline 9th decile household & 0.72 & 0.46 \\
\hline 10th decile household & 0.79 & 0.50 \\
\hline Average & 0.67 & 1.07 \\
\hline Firms & 0.79 & 0.52 \\
\hline Capital & -0.19 & 0.00 \\
\hline \multicolumn{3}{|l|}{ Macro-indicators } \\
\hline GDP & 0.87 & 0.55 \\
\hline Investment & -0.19 & 0.00 \\
\hline Domestic savings & -0.48 & -0.40 \\
\hline Private consumption & 0.67 & 1.12 \\
\hline Imports & -2.88 & -1.64 \\
\hline
\end{tabular}

\section{Table 8}

Hungary: Results of the simulations for 1990 (price and quantity variables in percentage deviations from SAM values)

\begin{tabular}{|c|c|c|c|c|c|c|c|c|}
\hline \multirow[b]{2}{*}{ Activities } & \multicolumn{4}{|c|}{ Simulation I } & \multicolumn{4}{|c|}{ Simulation II } \\
\hline & $\begin{array}{c}\text { nominal } \\
\text { output }\end{array}$ & $\begin{array}{c}\text { real } \\
\text { output }\end{array}$ & $\begin{array}{l}\text { output } \\
\text { prices }\end{array}$ & $\begin{array}{c}\mathrm{VA} \\
\text { prices }\end{array}$ & $\begin{array}{c}\text { nominal } \\
\text { output }\end{array}$ & $\begin{array}{c}\text { real } \\
\text { output }\end{array}$ & $\begin{array}{l}\text { output } \\
\text { prices }\end{array}$ & $\begin{array}{c}\text { VA } \\
\text { prices }\end{array}$ \\
\hline Agriculture & -0.18 & -0.36 & 0.18 & 0.84 & 0.16 & 0.01 & 0.15 & 0.57 \\
\hline Light industry & -0.77 & -0.44 & -0.33 & 0.58 & -0.20 & -0.06 & -0.14 & 0.52 \\
\hline Heavy industry & -1.12 & -0.83 & -0.29 & 0.47 & -0.61 & -0.45 & -0.16 & 0.34 \\
\hline Construction & 0.27 & -0.01 & 0.28 & 0.89 & 0.24 & 0.05 & 0.19 & 0.57 \\
\hline Services & 1.48 & 0.83 & 0.65 & 1.24 & 0.61 & 0.26 & 0.35 & 0.67 \\
\hline
\end{tabular}




\section{CONCLUDING REMARKS}

The application of CGE models to transitional economies, as done in this paper, is not meant to replicate real situations. These are too complex for any one prototype model. Instead, we chose to illuminate the role of externally financed government expenditure during a transitional period characterised by an increasing adoption of CGE conditions.

The economy that is modelled is seen to adjust to exogenous shocks by both quantity and price movements. However, since the economy is in market-clearing equilibrium in the benchmark period, total endowments of labour and capital are used at full capacity already. This implies that there is no opportunity for a general increase in production and income. External impulses can only generate additional production and income while price changes can generate the redistribution of income and production over the different actors in the economy.

In this CGE model external finance and the exchange rate were shown to play important roles. Public policy in the form of government expenditure, whether in the form of additional allocations to the service sector or as transfers which go to the poorest households, result in an increase in the government budget deficit. To rescue the transitional process from inflationary pressure, such a deficit needs to be financed from an additional inflow of foreign capital, which is now generally accepted by donors and recipients alike. This external capital inflow results in an appreciation of the exchange rate and thus changes the terms of trade in favour of the home country.

In both Poland and Hungary, the traditional export-oriented activities perform less. These results can be attributed to the exchange rate appreciation, which lead to a deterioration of the competitive position of domestic exporters.

Depending on the year and the type of government injection the production level in services and construction are consistently found to be higher than their baseline values. This effect is caused by the relatively strong linkage of these activities to each other and to investment and consumption. Heavy industry suffers most.

Growth of the GDP is found to be higher for Hungary than for Poland in three of the simulations done. In one simulation growth of GDP is higher in Poland than for Hungary. It needs to be added that the allocations to investment are always shown to be significantly higher for Poland than for Hungary, which could reflect higher growth potential in the longer run for Poland as compared to Hungary.

Additional income generated from the simulations is distributed regressively taking baseline data as a reference point. This is true for both countries even though the regressive tendency is higher in Poland than in Hungary. Moreover, 
the inequality mechanisms tend to intensify between 1987 and 1990 for Poland, while they remain the same for Hungary.

Of course, during these three years so many economic events have occurred and many overlapping policy measures were taken in many areas which do not pertain to the focus of the model. So it is very evident that our results may be overshadowed by such interventions. However, it is clear that more insight is gained if the CGE results are interpreted as indications of end situations once a transitional process is accomplished. Already now, about a decade since the transition started, there is empirical evidence in support of the simulations stated above and their corresponding results. Specially of interest here are the tendencies in both countries studied of an appreciation of the exchange rates, a change in composition of output towards more services and construction, less heavy industry, and more labour intensive factor use. Furthermore, Poland has been doing somewhat better than Hungary in investment and GDP growth, but this is coupled with more regressive income distribution patterns. Our results reveal these tendencies too.

In qualifying our results, it is important to state that the data base, which was once carefully compiled for the early nineties, is at many parts outdated now and needs to be supplemented as a proper basis for future policy analyses. Refinements can be also introduced in the formulation of the model. The more general CES functions can replace the Cobb-Douglas specifications we used. The assumption of immobile sectoral capital can be relaxed somewhat since buildings, vehicles, office equipment, etc., in transition economies were reallocated between sectors. The tax system is also oversimplified in the model, but this can be refined depending on the focus of the policy analysis.

\section{REFERENCES}

Cohen, S. I. (1993): Patterns of Economic Restructuring for Eastern Europe. Aldershot, England: Avebury, Ashgate Publishing Ltd.

Cohen, S. I., Braber, M. C., Révész, T. and Zolkiewski, Z. (1996): Policy modelling under fixed and flexible price regimes: SAM-CGE transitional applications to Poland and Hungary. Journal of Policy Modelling, 8 (5): 495-529.

Commander, S. and Coricelli, F. (1992): Price-wage dynamics and inflation in socialist economies: Empirical models for Hungary and Poland. World Bank Economic Review, 6 (1): 33-53.

Kracun, D. (1991): Inflation model of a semi-command economy. Economic Modelling, 8 (4): $512-527$.

Xu, D. (1993): Price distortion in the transition process: A CGE analysis of China's case. Economics of Planning, 26 (2): 161-182. 
